\title{
Spatiotemporal Variation of the Climatic Signal of Tree-Rings Chronology of the Pine Belt and Priobie Pine Forests
}

\author{
Natalia V. Rygalova and Nikolay I. Bykov* \\ Altai State University \\ 61 Lenin, Barnaul, 656049, Russia
}

Received 12.03.2015, received in revised form 18.05.2015, accepted 11.10.2015

The results of the dendrochronological study of the pine belt and Priobie pine forests of the Altai Territory, growing in the forest-steppe and steppe zones, are presented. The usage of regular network of 36 study plots allowed us to conduct a detailed research of the features of the growth of Scots pine in various zonal conditions (track changes in the climate signal from the southern forest to the dry steppe). On the basis of the cluster analysis two zonal groups of chronologies (forest-steppe and steppe) were received, and it showed the manifestation of the mesoclimatic signal in the tree-ring series. Comparative valuation of the cluster analysis results, of sensitivity and cross-series correlations coefficients, of climatic response of pine in the first and second halves of the XX century, which were characterized by different hydrothermal regime, was conducted. As a consequence the climatic signal attenuation in the first half of the XX century in favorable conditions for the growth of pine (cooler and more humid conditions) was discovered.

Keywords: dendroclimatology, climatic signal, pine belt forest, Priobie pine forest, cluster analysis of tree-ring chronology, forest-steppe and steppe zones.

DOI: 10.17516/1997-1389-2015-8-4-394-409.

(c) Siberian Federal University. All rights reserved

* Corresponding author E-mail address: natalia.ml@mail.ru,bykov@mail.ru 


\title{
Пространственно-временная изменчивость
}

\section{климатического сигнала}

\section{древесно-кольцевых хронологий \\ ленточных и Приобских боров}

\author{
Н.В. Рыгалова, Н.И. Быков \\ Алтайский государственный университет \\ Россия, 656049, Барнаул, пр. Ленина, 61
}

В статье представлены результаты дендрохронологического исследования ленточных $и$ Приобских боров Алтайского края, произрастающих в лесостепной и степной зонах. Созданная регулярная сеть из 36 модельных площуадок позволила провести детальное исследование особенностей прироста сосны обыкновенной в различных зональных условиях (проследить изменение климатического сигнала от южной лесостепи до сухой степи). Кластерньй анализ выявил две зональные группы хронологий (лесостепная и степная), что свидетельствует о проявлении мезоклиматического сигнала в древесно-кольцевых рядах. Проведена сравнительная оценка результатов кластерного анализа, коэффициентов чувствительности и межсериальной корреляции, значений климатического отклика сосны в первой и второй половинах XX в., характеризующихся различным гидротермическим режимом. В результате было установлено ослабление связи хронологий с климатом в первой половине XX в. в благоприятных для роста сосны условиях (в более прохладных и влажных).

Ключевые слова: дендроклиматология, климатический сигнал, ленточные боры, Приобские боры, кластерный анализ хронологий, лесостепная и степная зона.

\section{Введение}

Климатический сигнал (регистрируемая в годичных кольцах информация о лимитирующем влиянии климата) в хронологиях подвержен изменению во времени и пространстве. Если значение территориального фактора в проявлении дендроиндикационного потенциала понятно и многократно рассмотрено в ряде научных работ (от топологического до макрорегионального уровня), то изучению флуктуаций климатического сигнала в разные периоды времени уделено меньше внимания. Подобные работы особенно значимы для территорий, климатические условия которых характеризуются как слабо экстремальные (коэффициент чувствительности древесно-кольцевых хронологий таких участков колеблется около 0,2), например для южного предела распространения древесных растений. Отдельные дендроклиматические исследования в переходной зоне между лесостепью и степью на территории России и бывшего СССР проводились и ранее (Андреев и др., 2001; Агафонов, Кукарских, 2008; Бабушкина, Белокопытова, 2014; Глызин и др., 2005; Дмитриева, 1982; Магда, 2003; Матвеев, 2004; Оленин, Мазепа, 1988; Пугачев, 1975; Тишин, 2008 и др.). Однако в связи с тем, что ширина прироста деревьев в условиях близкого к оптимальному (лесостепь) и засушливого 
(степь) климата зависит от набора лимитирующих факторов, которые могут меняться во времени и пространстве, для этой территории необходимо увеличивать частоту региональных исследований.

Объектом нашего исследования стали древесно-кольцевые хронологии сосны обыкновенной (Pinus sylvestris L.) ленточных и Приобских боров, произрастающих в континентальной части России на юге Западной Сибири. Ранее дендроклиматические исследования ленточных боров проводились С.М. Олениным и В.С. Мазепой (Оленин, Мазепа, 1988), которые изучали цикличность прироста сосны казахской части ленточных боров и возможность прогноза его динамики, и В.Н. Магда (Магда, 2003), который сравнивал прирост сосны ленточных боров с радиальным ростом деревьев на верхней и нижней границах леса в горах Алтая. В настоящей статье приведены результаты оценки мезоклиматического сигнала в годичных кольцах ленточных и Приобских боров и предпринята попытка установить особенности его пространственной и временной дифференциации в контактной зоне «лесостепь-степь».

\section{Материалы и методы}

Работа основана на анализе 36 обобщенных хронологий ширины годичных колец сосны обыкновенной Приобских и ленточных боров. Последние представляют собой реликтовые интразональные леса (Вангниц, 1953; Грибанов, 1954), которые произрастают в древних ложбинах стока талых вод (Лютцау, 1970) и параллельными полосами протягиваются от южной лесостепи до сухой степи (пересекая четыре физико-географические подзоны), образуя южный предел распространения сосны обыкновенной по широте (Правдин, 1964, с. 19). Это обстоятельство делает данную лесную геосистему научной площадкой для изучения межзональных климатических изменений (рис. 1). В отличие от ленточных боров, которые сформировались на мощных средне- и верхнечетвертичных песчаных отложениях флювиального и эолового генезиса (Адаменко, 1974; Лютцау, 1970), Приобские сосновые леса являются примером современных интразональных лесных ландшафтов, расположенных на правом берегу р. Оби и приуроченных к подзоне южной лесостепи. В данной работе исследован прирост сосны обыкновенной в Верхне-Приобском бору.

Рельеф ленточных боров характеризуется как грядово-бугристый (Вангниц, 1953), при этом на северо-востоке он более пологий (разница между вершиной гряд и днищем ложбины составляет 1-3 м), при движении на юго-запад высота увалов относительно понижений увеличивается до 30-40 м. Абсолютная высота днищ большей части Барнаульской и Касмалинской ложбин составляет 200-220 м, Кулундинской - 140-150 м, Бурлинской - 170180 м (Занин, 1958). Днища ложбин характеризуются как увлажненные местообитания в связи с более близким залеганием грунтовых вод (в межбугровых понижениях глубина залегания составляет в среднем 1,5 м, на буграх - 6 м, в юго-западной части ложбин глубина залегания грунтовых вод в западинах составляет менее 1 м, что часто приводит к выходу вод на поверхность (Вангниц, 1953)). В понижениях между гривами могут располагаться болота или озера, в одноименных боровых лентах берут начало и протекают реки Кулунда, Бурла (область внутреннего стока), Касмала, Барнаулка (бассейн р. Оби). Территория Верхне-Приобского бора приурочена ко второй, третьей и четвертой террасам р. Обь (средняя высота составляет 130-200 м), для нее характерна заболоченность местно- 


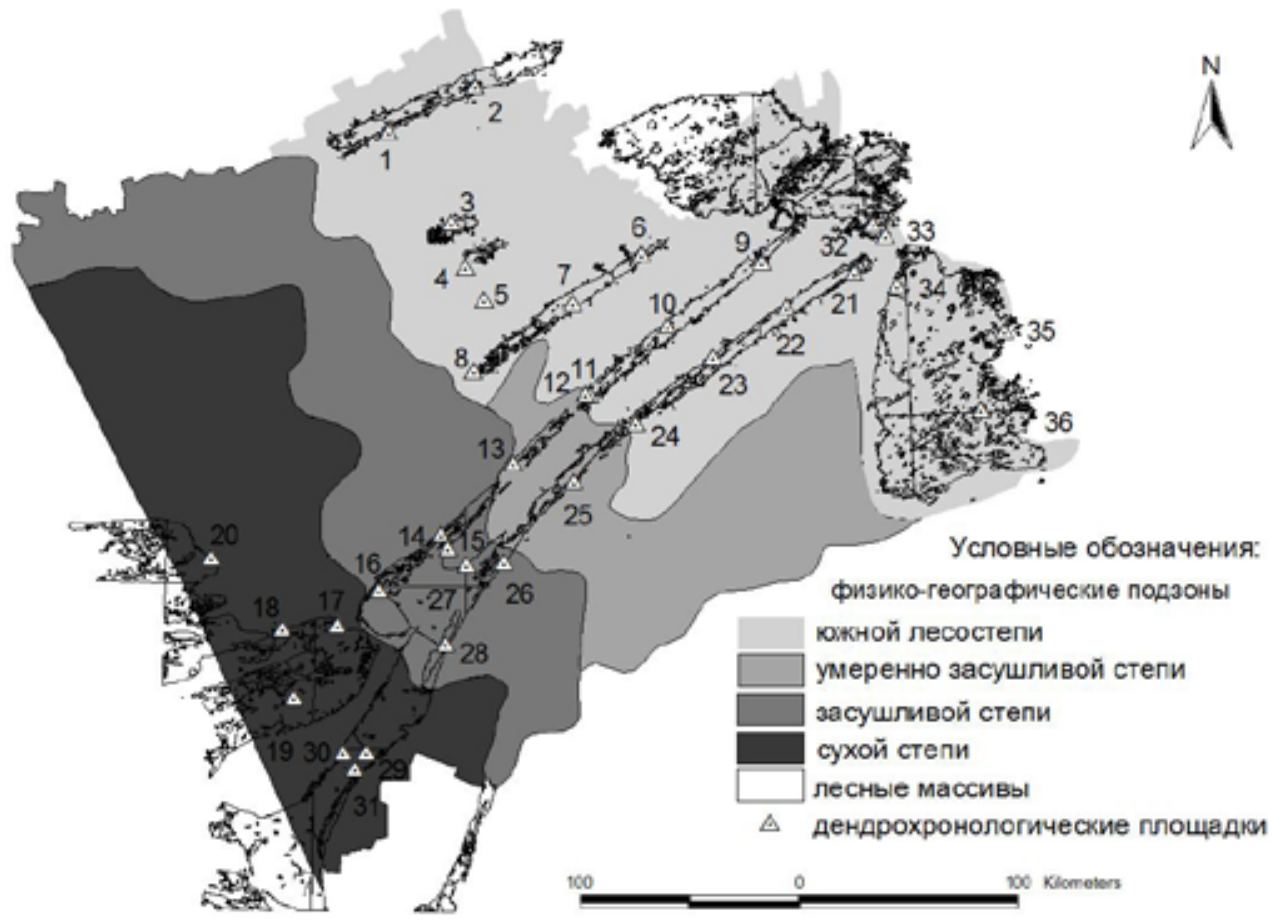

Рис. 1. Физико-географическая характеристика территории исследования (Алтайский край. Атлас, 1978) и месторасположение пунктов отбора образцов сосны обыкновенной: Цифрами на карте обозначены дендрохронологические площадки: Алеусская лента: 1 - Подойниково, 2 - Долганка; боровые массивы: 3 Корнилово, 4 - Капустинка, 5 - Паклино; Кулундинская лента: 6 - Ивановка, 7 - Шарчино, 8 - Завьялово; Касмалинская лента: 9 - Павловск, 10 - Ребриха, 11 - Буканское, 12 - Мамонтово, 13 - Гуселетово, 14 - Солоновка, 15 - Малышев Лог, 16 - Волчиха; Гатский бор: 17 - Бычье, 18 - Михайловское, 19 Малиновое озеро; Чалдайский бор: 20 - Северка; Барнаульская лента: 21 - Барнаул, 22 - Черемное, 23 Зимино, 24 - Боровское, 25 - Андреевка, 26 - Токарево, 27 - Полевой стан, 28 - Горькое-Перешеечное, 29 - Угловское-42(97), 30 - Угловское-120(97), 31 - Угловское; Приобский бор: 32 - Кармацкий, 33 Велижановка, 34 - Бобровка, 35 - Троицкое, 36 - Уткуль

сти, при этом возвышенные участки характеризуются как более сухие местообитания.

Территория исследования расположена в зоне континентального климата, который принимает черты резко-континентального в юго-западной части. Климатические условия характеризуется неустойчивым режимом увлажнения, сильными ветрами, низкой относительной влажностью воздуха, часто опускающейся до 30 \% (Вангниц, 1953). Среднегодовые температуры (как и температуры летнего периода) повышаются на территории исследования с севера на юг на $2,3{ }^{\circ} \mathrm{C}$ (табл. 1). При этом снижение количества осадков происходит в субширотном направлении (в связи с барьерным эффектом Алтае-Саянской горной системы): с северо-востока на юго-запад и на запад на 125-150 мм (табл. 1). Территория Приобского бора по сравнению с ленточными борами характеризуется как более увлажненная, увеличение количества осадков происходит с севера (420 мм) на юго-восток (более 500 мм). Большая часть атмосферных осадков выпадает в теплый период года, при этом летом обычны суховеи и очень низкая относительная влажность воздуха, что лимитирует продуктивность и крайне вредно сказывается на росте всходов сосны (Шиманюк, 1962).

В период с 2003 по 2013 г. на территории исследования было заложено 36 модельных 
Таблица 1. Климатическая характеристика района исследования (средние значения приведены за период 1970-2000 гг.)

\begin{tabular}{|c|c|c|c|c|}
\hline Метеостанция & $\begin{array}{c}\text { Физико- } \\
\text { географическая } \\
\text { подзона* }\end{array}$ & $\begin{array}{c}\text { Расположение метеостанции } \\
\text { относительно боровых массивов }\end{array}$ & $\begin{array}{c}\text { Среднегодовая } \\
\text { температура, }{ }^{\circ} \mathrm{C}\end{array}$ & $\begin{array}{c}\text { Годовое } \\
\text { количество } \\
\text { осадков, мм }\end{array}$ \\
\hline Бийск & Средняя лесостепь & $\begin{array}{l}\text { Юго-восточная часть Верхне- } \\
\text { Приобского бора }\end{array}$ & 2,1 & 535 \\
\hline Камень-на-Оби & Южная лесостепь & $\begin{array}{l}\text { Между Алеусской лентой и } \\
\text { боровыми островами }\end{array}$ & 1,3 & 327 \\
\hline Барнаул & Южная лесостепь & $\begin{array}{l}\text { Северо-восточная часть } \\
\text { Барнаульской ленты }\end{array}$ & 2,2 & 421 \\
\hline Волчиха & Засушливая степь & $\begin{array}{l}\text { Центральная часть } \\
\text { Касмалинской ленты в районе ее } \\
\text { слияния с Барнаульским бором }\end{array}$ & 2,2 & 350 \\
\hline Угловское & Сухая степь & $\begin{array}{l}\text { Юг Барнаульского ленточного } \\
\text { бора }\end{array}$ & 3,6 & 297 \\
\hline Ключи & Сухая степь & Чалдайский бор & 3,0 & 265 \\
\hline
\end{tabular}

*Приведено согласно источнику: Алтайский край. Атлас, 1978, с. 151.

площадок для отбора буровых образцов сосны в Приобском бору (Верхне-Приобском), в четырех боровых лентах (Алеусской, Кулундинской, Касмалинской и Барнаульской), в Гатском, Чалдайском борах и отдельных боровых массивах Каменского и Баевского районов Алтайского края (исключение: для построения хронологии «Бобровка» Приобского бора были использованы поперечные спилы). В административно-территориальном отношении территория исследования располагается в границах Алтайского края. Для изучения характера пространственного изменения связи динамики климата и ширины годичных колец деревьев модельные участки в ленточных борах закладывались примерно через каждые 50 км (рис. 1). Сбор, обработка кернов деревьев, измерение (при использовании LINTAB; TSAP), датировка (COFECHA) и стандартизация (ARSTAN) проводились по стандартной, общепринятой методике (Шиятов и др., 2000; Cook, Kairiukstis, 1990; Grissino-Mayer, 2001; Holmes, 1983; Rinn, 1996).

Характеристика полученных древеснокольцевых хронологий проводилась по физико-географическим подзонам в связи с большим массивом данных (табл. 2). Из этих же соображений хронологии, принадлежащие подзоне умеренно засушливой степи и засушливой степи, рассмотрены вместе. Средний возраст проанализированных деревьев составляет 150 лет, самой длинной хронологией (280 лет, 1733-2013 гг.) является ряд «Малиновое озеро» (сухая степь).

Опираясь на ранее проведенные исследования, в ходе которых было установлено наличие связи между климатическими факторами и приростом сосны ленточных боров, предпринята попытка изучить его пространственно-временную дифференциацию с помощью кластеризации хронологий. Выбор кластер-анализа в качестве инструмента оценки пространственной изменчивости климатического сигнала обоснован тем, что данный метод позволяет во множестве данных, выявив внутренние связи, выделять однородные (с одинаковыми параметрами) совокупности наблюдений (Мандель, 1988). В случае кластерного анализа древеснокольцевых рядов объединение в классы про- 
Таблица 2. Статистическая характеристика хронологий, сгруппированных по физико-географическим подзонам

\begin{tabular}{|c|c|c|c|c|c|c|c|c|}
\hline & & 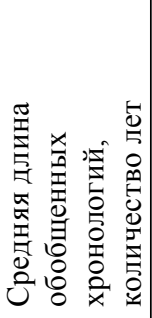 & 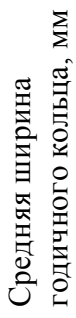 & 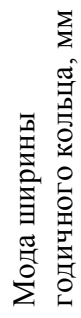 & 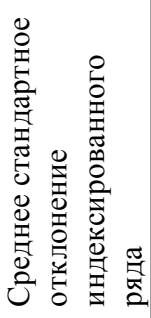 & 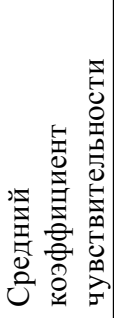 & 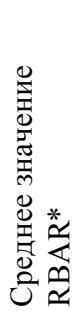 & 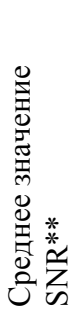 \\
\hline \multicolumn{2}{|c|}{$\begin{array}{l}\text { Хронологии южной лесостепи (Приобские } \\
\text { боры) }\end{array}$} & 106 & 1,76 & 1,00 & 0,19 & 0,20 & 0,50 & 13,70 \\
\hline \multirow{3}{*}{ 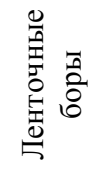 } & хронологии южной лесостепи & 140 & 2,14 & 1,48 & 0,18 & 0,19 & 0,56 & 19,22 \\
\hline & хронологии засушливой степи & 136 & 2,13 & 1,44 & 0,19 & 0,21 & 0,59 & 27,07 \\
\hline & хронологии сухой степи & 180 & 1,91 & 1,01 & 0,20 & 0,21 & 0,63 & 31,67 \\
\hline
\end{tabular}

* - средний коэффициент корреляции индивидуальных серий друг с другом;

** - отношение сигнала к шуму (Cook, Kairiukstis, 1990)

исходит по принципу схожести хронологий, когда деревья испытывают влияние одних и тех же лимитирующих факторов. Таким образом, можно предположить, что выделяемые в процессе кластерного анализа группы древесно-кольцевых рядов характеризуются общим сигналом. Метод кластеризации массивов данных нашел широкое применение в экологии, географии и биологии (Пузаченко, 2004), а также в дендроклиматических исследованиях (Магда, 2003; Магда и др., 2004; Cook, Kairiukstis, 1990; Garcia-Gonzalez, 2008; Koese et al., 2012).

Для изучения пространственных связей между приростом сосны на различных модельных участках ленточных боров были взяты значения хронологии сосны с 1903 по 1997 г. (этот временной отрезок представлен всеми 36 хронологиями). В качестве способа кластеризации был выбран метод Уарда, при котором для оценки расстояний между кластерами используется дисперсионный анализ (Пузаченко, 2004, с. 300), мерой дистанции между группами определено евклидово расстояние (Мандель, 1988, с. 32).

\section{Результаты и обсуждение}

Коэффициент чувствительности обобщенных древесно-кольцевых серий удовлетворителен (колеблется от 0,16 до 0,25), в пространственном отношении отмечается его общее увеличение в направлении от лесостепных местообитаний к сухостепным (рис. 2). Подобные пространственные зависимости проявляются и в изменении RBAR. Отношение сигнала к шуму также трансформируется в направлении увеличения сухости климата в сторону роста сигнала. В ходе анализа генеральных совокупностей хронологий, выделенных по физико-географическим подзонам, был установлен зональный характер зависимости динамики прироста сосны от климатических факторов. Однако на уровне отдельных обобщенных хронологий подобная закономерность может нарушаться. Это связано с влиянием локальных экологических факторов на особенности радиального роста сосны, что уже отмечалось ранее для территорий со слабо экстремальными климатическими условиями (Бабушкина и др., 2011). 


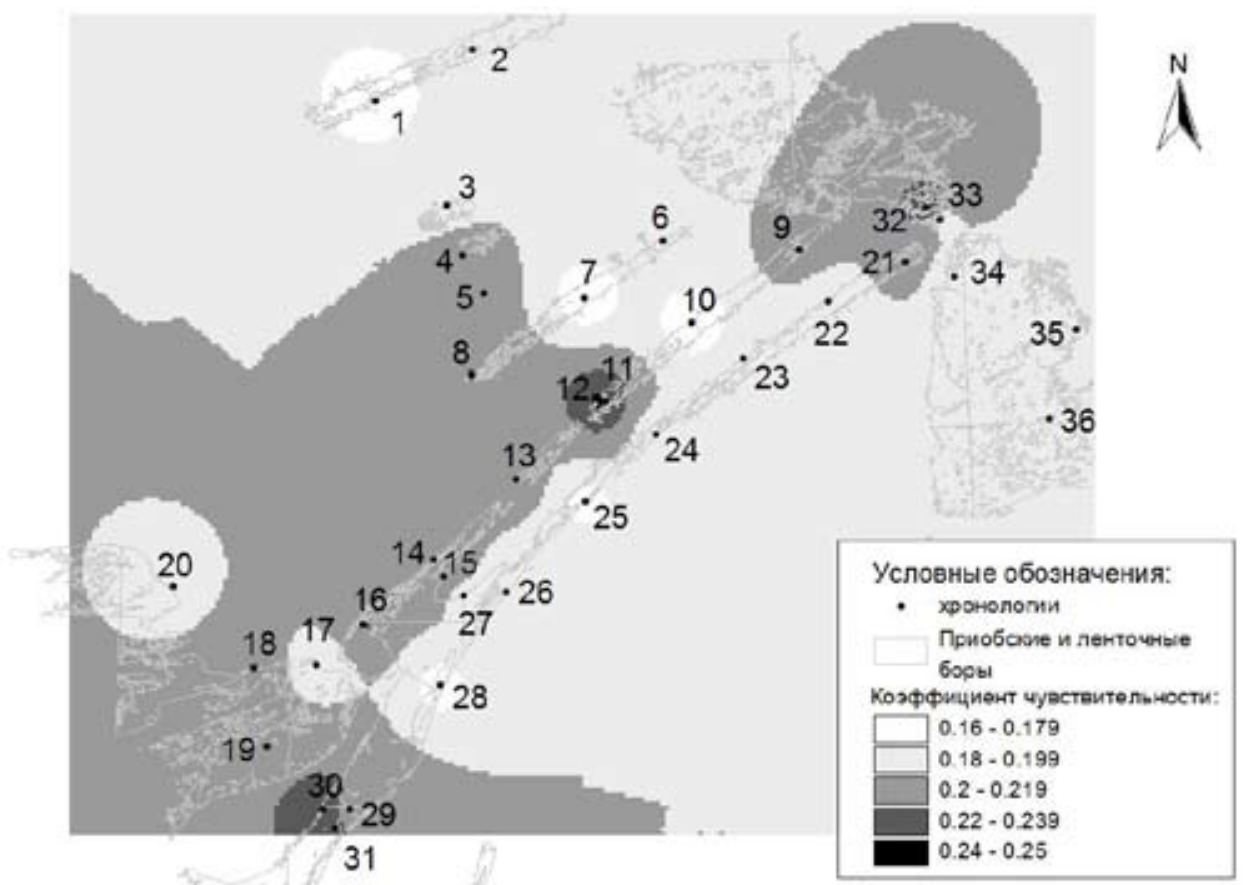

Рис. 2. Пространственная модель изменения коэффициента чувствительности древесно-кольцевых хронологий Приобских и ленточных боров (названия хронологий см. рис. 1)

Ранее проведенный (Малышева, 2013) многофакторный регрессионный анализ показал, что для прироста сосны в лесостепной зоне наиболее значимы осадки июня-июля (положительная связь) и температуры июня (отрицательная), величина прироста сосны в степной зоне лимитирована преимущественно температурой мая (значимость осадков при этом оказывается ниже) ${ }^{1}$. Данная зависимость объясняется тем, что ограничивающее значение температуры увеличивается при повышении сухости климата, что согласуется с полученными ранее выводами по Южному Уралу (Агафонов, Кукарских, 2008). При этом среднее значение общих коэффициентов множественной регрессии хронологий сосны и месячных рядов осадков и температуры вегетационного периода составило 0,6 (от 0,44 до 0,78), что существенно выше значений парной корреляции. Это доказывает наличие многокомпонентного климати- чески обусловленного сигнала в древеснокольцевых рядах.

Зональные различия в динамике прироста сосны ленточных боров были установлены посредством кластерного анализа, который позволил выделить хронологии, группирующиеся по физико-географическим зонам (рис. 3). Пороговое стандартизированное расстояние кластеризации, определяющее статистически корректное количество групп, в данном случае равно 2,7. Это означает, что дендроряды объединяются в два крупных кластера, условно называемые «степной» и «лесостепной». Группа «степных» хронологий (территориально приуроченных к зоне сухой и засушливой степи) образована из локальных подкластеров, выделяемых по принципу территориальной близости. При этом особняком стоит комбинация «МихайловскоеСеверка-Паклино-Капустинка», которая объединяет сухостепные древесно-кольцевые 


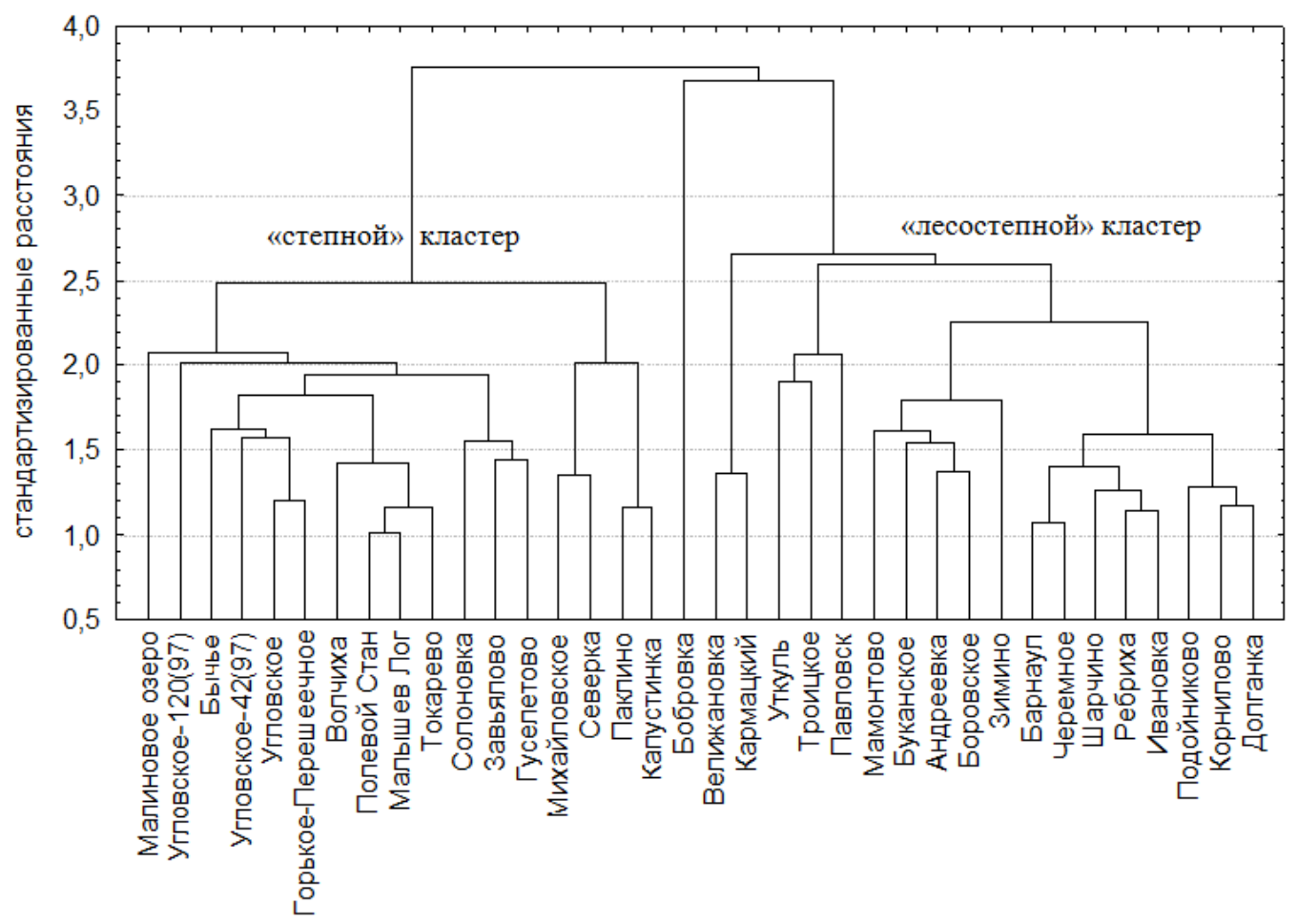

Рис. 3. Дерево кластеризации обобщенных хронологий сосны Приобских и ленточных боров Алтайского края за период 1903-1997 гг.

ряды (первые две) и хронологии, построенные по небольшим боровым массивам в южной лесостепи, которые представлены возвышенными сухими местообитаниями. «Лесостепной» кластер включает группы хронологий, приуроченных к более прохладным и влажным территориям: древеснокольцевые ряды возвышенных (более сухих) участков («Кармацкий-Велижановка») и влажных местообитаний приобских боров («Уткуль-Троицкое-Павловск», при этом «Павловск» - это самая северная модельная площадка Касмалинского бора, приближенная к пойме Оби), лесостепные хронологии более влажных (северных) и более сухих (южных) местообитаний. Отдельно выделяется хронология «Бобровка», которая построена по участку, характеризующемуся высокой степенью переувлажнения (вблизи р. Обь).
Тот факт, что в результате кластерного анализа древесно-кольцевых рядов достаточно четко обосабливаются хронологии степной и лесостепной зон, позволяет говорить о значительных различиях в динамике прироста сосны обыкновенной на севере и на юге ленточных боров. Это согласуется с проведенными ранее ботаническими исследованиями (Стрелковский, 2005), в которых на основании морфологических признаков выделяется два экотипа сосны обыкновенной боровых лент (лесной - на севере и степной или кулундинский - на юге). Приблизительная граница между распространением двух подвидов сосны проходит по $52^{\circ}$ с.ш. П.Р. Вангниц указывает параллель 52³0' с.ш., разделяющую ленточные боры на северо-восточную (прохладную и влажную) и юго-западную (более сухую и теплую) части (Вангниц, 1953). Тер- 


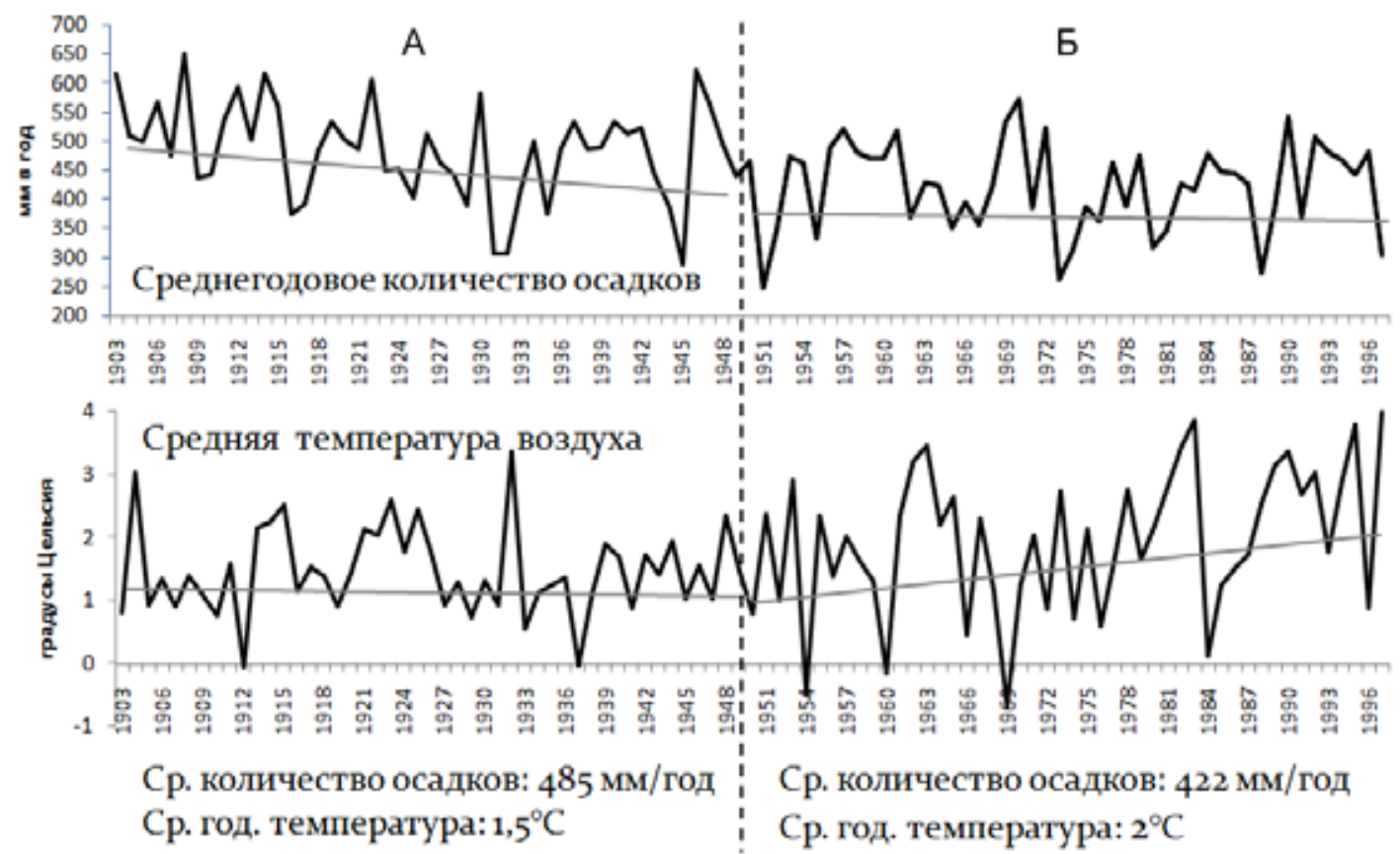

Рис. 4. Климатическая характеристика периодов исследования: 1903-1950 гг. (А) и 1950-1997 гг. (Б) по данным метеостанции Барнаул

риториальная граница между двумя кластерными ареалами сосны, установленная нами в ходе исследования, проходит также в этом широтном диапазоне.

Для изучения пространственновременной динамики древесно-кольцевых рядов использовался разновременной кластерный анализ хронологий в XX в. Выбранные периоды (1903-1950 и 1951-1997 гг.) характеризуются различными климатическими условиями: первая половина ХХ в. более влажная и прохладная по сравнению со второй (рис. 4).

Группировка хронологий во второй половине прошлого века (1950-1997 гг.) отражает современную зональную картину (рис. 5). Подавляющее большинство хронологий «степных» групп расположено на территории, где ГТК меньше 1 (гидротермический термический коэффициент Селянинова, равный 1 , принят как климатическая граница между лесостепью и степью). Территорию островных боров (между Бурлинской и Кулундинской лентами) относят (Занин и др., 1955) к зоне степей по своим природно-климатическим характеристикам. Кластеризация хронологий в первой половине ХХ в. (1903-1950 гг.) имеет ряд отличий от современной. Кластерное дерево древесно-кольцевых серий в первой половине XX в. менее структурированное, происходит сближение групп дендрорядов «степи» и «лесостепи». При этом обосабливается кластер северо-восточных (более влажных) лесостепных хронологий. Это происходит на фоне более прохладного и влажного климата. По данным метеостанции Барнаул, первая половина XX в. характеризуется по сравнению со второй половиной более значительным понижением среднегодовой температуры (на 25 \% ниже), чем увеличением осадков (только на 14 \% больше). Этот факт мог отразиться на продуктивности древесных растений (лимитирующее влияние тем- 


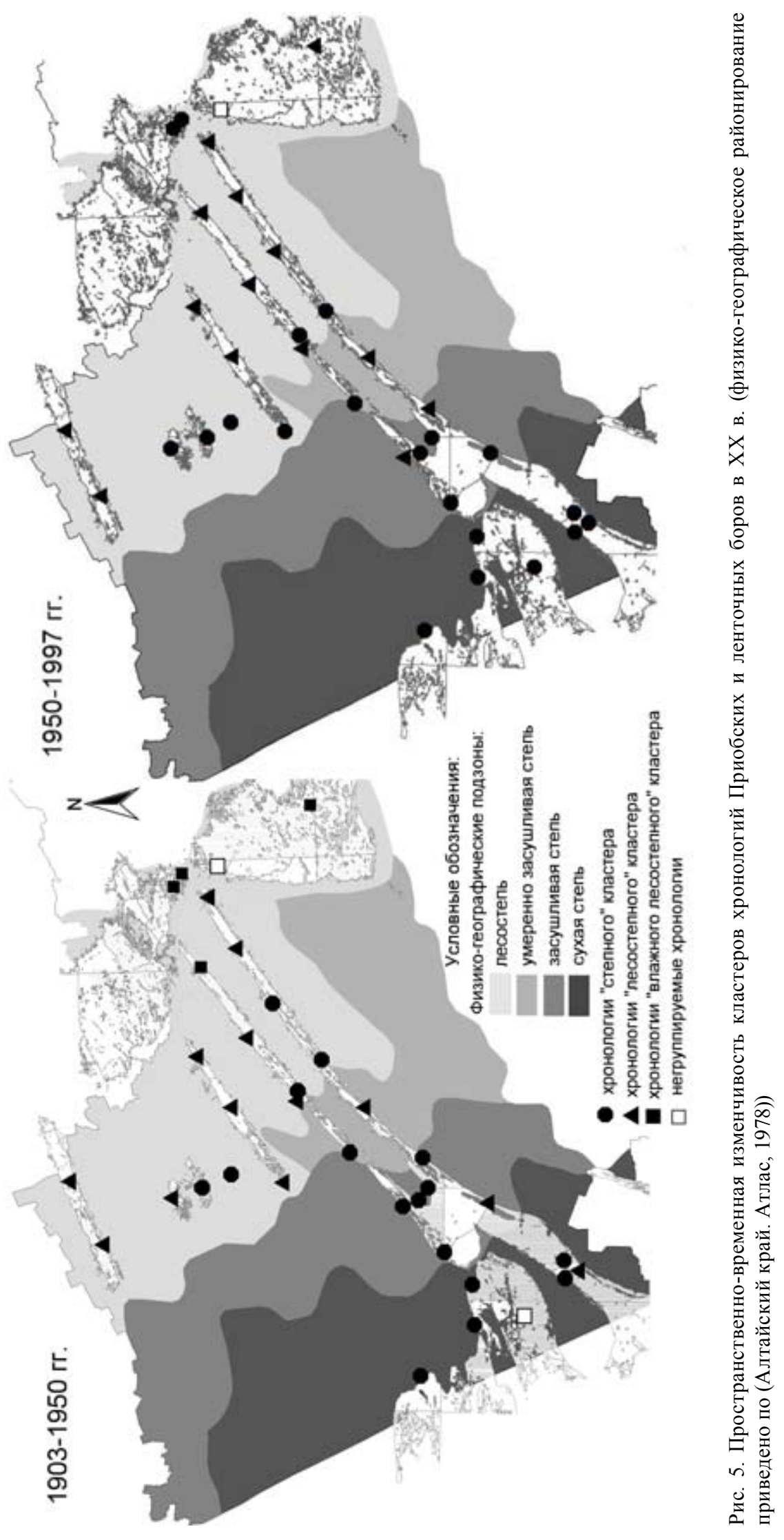


пературного фактора на прирост в первой половине прошлого века было менее выражено, чем во второй половине), что, в свою очередь, отразилось на перегруппировке хронологий в кластерном дереве. С одной стороны, в начале XX в. отмечалось небольшое продвижение на юго-запад лесостепных хронологий. С другой - некоторая рассогласованность в выделении дендрокластеров может объясняться тем, что древесные растения, не испытывающие угнетающего влияния летних высоких температур как в зоне степи, так и южной лесостепи, продуцируют схожим образом. Это говорит о том, что пространственный ареал экологического оптимума для произрастания сосны обыкновенной в начале $\mathrm{XX}$ в. был шире. Увеличение температуры и снижение осадков во второй половине ХХ в. приводит к более четкому обособлению хронологий степной и лесостепной зоны.

Для исследования изменчивости климатического сигнала древесно-кольцевых хронологий во времени также были сопоставлены коэффициенты чувствительности и межсериальной корреляции обобщенных дендрорядов в первой и второй половине ХХ в. (рис. 6). В 85 \% случаев фиксируется увеличение значений коэффициентов чувствительности хронологий во второй половине ХХ в., в период с более экстремальными климатическими условиями (рис. 4). Подобная ситуация характерна и для межсериальной корреляции: во второй половине прошлого века наблюдается увеличение значений коэффициентов. Статистические расчеты подтвердили результаты кластерного анализа: в благоприятные для роста периоды отмечается рассогласованность прироста, что может быть связано с ослаблением мезоклиматического сигнала в годичных кольцах деревьев, при этом начинают играть роль локальные факторы местообитаний.
Также были сопоставлены осредненные коэффициенты корреляции всех хронологий ленточных и Приобских боров с рядами температуры и осадков теплого периода года за 1903-1950 и 1950-1997 гг. (рис. 7). Метеоданные были взяты по станции Барнаул, продолжительность наблюдений которой охватывает изучаемые временные интервалы. Полученные значения указывают на более слабый климатический сигнал в первой половине ХХ в. по сравнению со второй половиной. Это подтверждает высказанные ранее предположения.

Во второй половине прошлого века (более сухой и теплой) отмечается увеличение значимости осадков апреля-августа (исключая май) и температуры мая-июля. Рост значения осадков апреля для прироста сосны при потеплении климата может быть связан с более ранним наступлением вегетационного периода. Подобное явление - уменьшение синхронности динамики радиального прироста и колебаний температуры/осадков в периоды климатического оптимума - отмечалось и ранее для произрастания сосны в степной зоне (Оленин, Мазепа, 1988). При увеличении экстремальности климата прослеживается объединяющее влияние лимитирующего фактора (отмечается выраженность климатического сигнала) и как результат - согласованность прироста, рост климатического отклика хронологий.

\section{Заключение}

Радиальный прирост сосны интразональных ленточных и Приобских боров имеет пространственную неоднородность климатического сигнала. С помощью кластерного анализа древесно-кольцевых хронологий было выделено два зональных ареала произрастания сосны обыкновенной (степной 


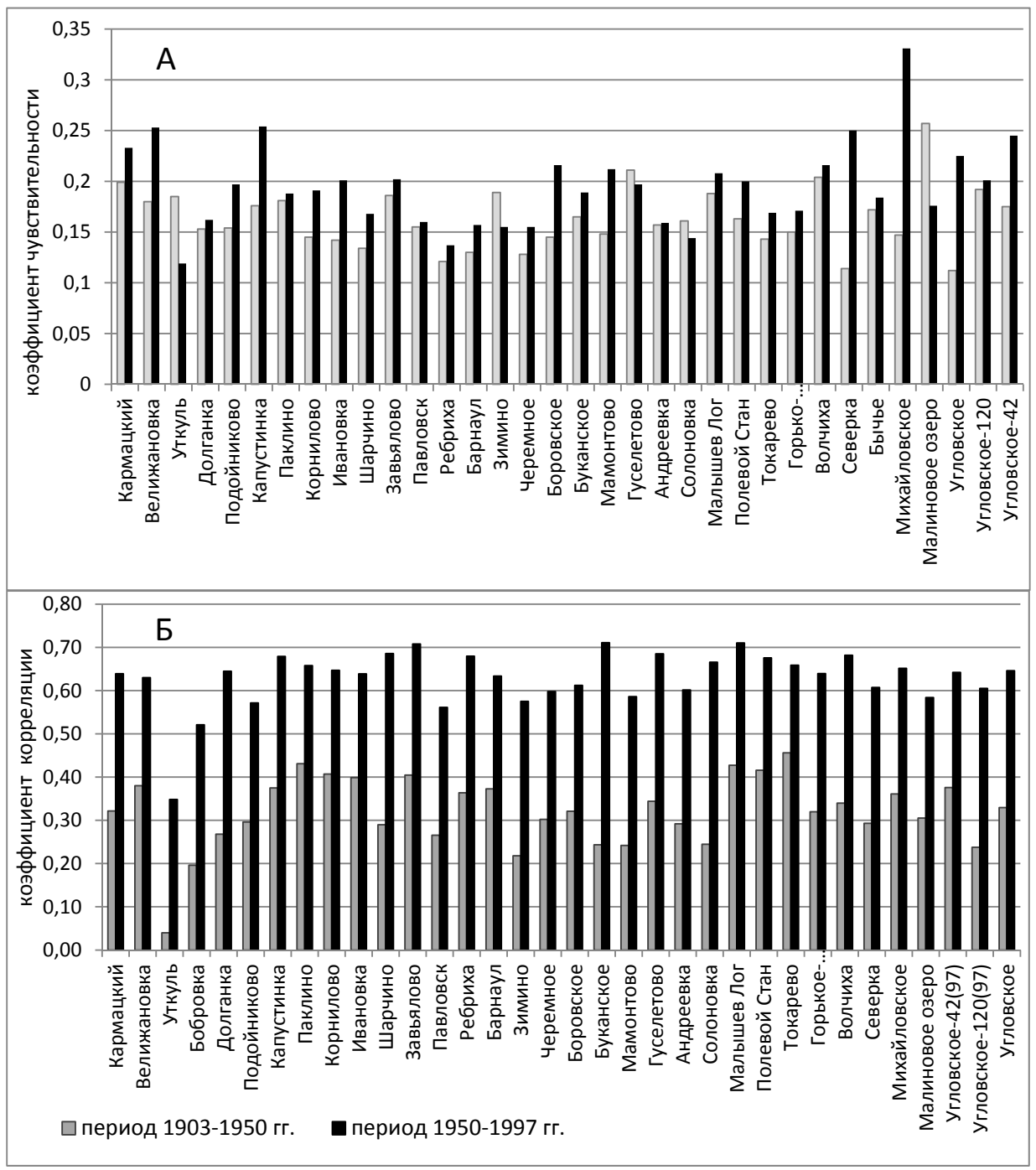

Рис. 6. Изменение коэффициентов чувствительности (А) и межсериальной корреляции (Б) обобщенных хронологий Приобских и ленточных боров в первой и второй половине XX в.

и лесостепной), характеризующихся отличными друг от друга экотипами.

На протяжении XX в. отмечалась нестабильность климатического отклика сосны ленточных и Приобских боров: в первой половине столетия (более прохладной и влажной по сравнению со второй) корреляция древесно-кольцевых рядов с гидротермическим режимом теплого периода года была в 1,5-2 раза меньше, чем во второй половине. Первая половина XX в. характеризуется рас- согласованностью динамики радиального прироста сосны в разных частях ленточных боров, пониженными значениями коэффициентов чувствительности и межсериальной корреляции обобщенных серий, что свидетельствует об ослаблении зависимости прироста сосны от климатического фактора. В таких благоприятных условиях усиливается значимость локальных факторов местообитаний для роста деревьев, которые трансформируют климатический сигнал. Этот 


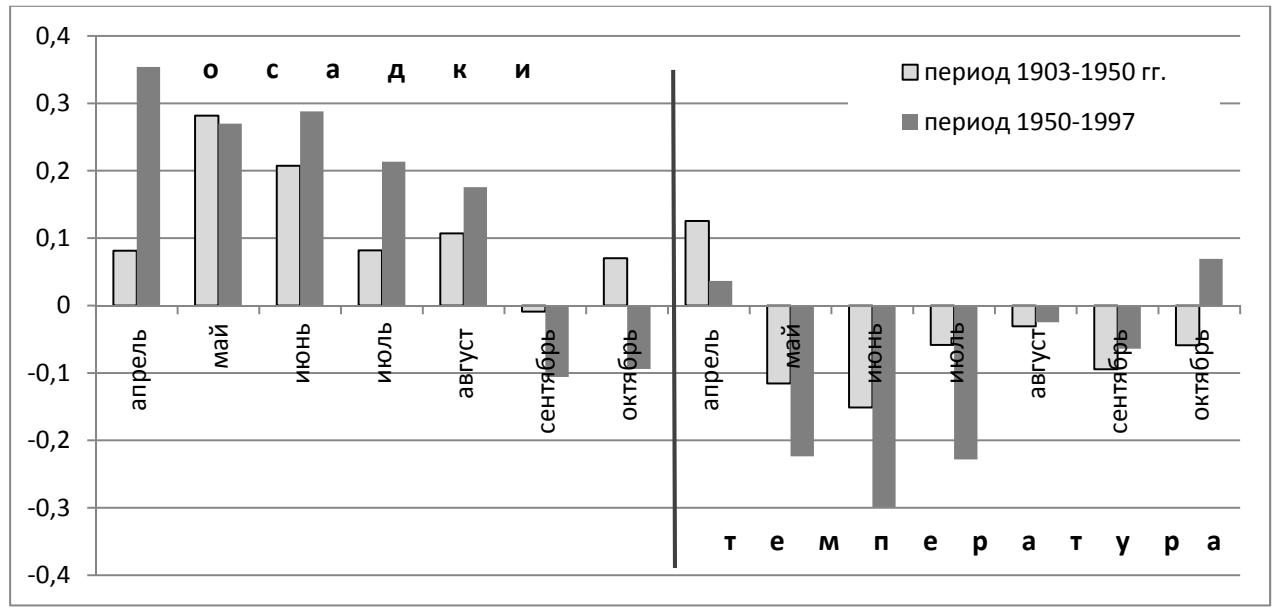

Рис. 7. Осредненные коэффициенты корреляции всех хронологий ленточных и Приобских боров с рядами температуры и осадков теплого периода года (по данным метеостанции Барнаул) в первой и второй половинах XX в.

факт оставляет открытым вопрос о точности реконструкции климата прошлого на основе установленных статистических зависимостей за определенный (современный) промежуток времени для территорий со слабо экстремальными климатическими условиями.

Работа была подготовлена к публикации при поддержке Программы стратегического развития ФГБОУ ВПО «Алтайский государственный университет» на 2012-2016 г2. в рамках конкурса «Академическая мобильность-2014».

\footnotetext{
Для регрессионного анализа использовались данные метеостанций Барнаул, Хабары, Баево, Алейск, Ребриха, Мамонтово, Волчиха, Угловское, Ключи за период с 1950 по 2000 г. (метеостанции выбирались по принципу максимально близкого расположения к точкам хронологий).
}

\section{Список литературы}

Агафонов Л.И., Кукарских В.В. (2008) Изменение климата прошлого столетия и радиальный прирост сосны в степи Южного Урала. Экология, 3: 173-180 [Agafonov L.I., Kukarskikh VV. (2008) Climate change in the last century and radial growth of pines in the Southern Urals steppe. Ecology [Ekologiia], 3: 173-180 (in Russian)]

Адаменко О.М. (1974) Мезозой и кайнозой Степного Алтая. Новосибирск, Наука, 167 с. [Adamenko O.M. (1974) Mesozoic and Cainozoic Eras of the Altai Steppe. Novosibirsk, Nauka, 167 p. (in Russian)]

Алтайский край. Атлас (1978) Т. І. М., Барнаул, ГУГК, 222 с. [Altai (Krai) Territory. Atlas (1978) Vol. 1. Moskow, Barnaul, Main Department of Geodesy and Cartography, 222 p.]

Андреев С.Г., Тулохонов А.К., Наурзбаев М.М. (2001) Региональные закономерности изменчивости прироста сосны в степной зоне Бурятии. География и природные ресурсы, 1: 49-53 [Andreev S.G., Tulokhonov A.K, Naurzbaev M.M. (2001) Regional factors of variability of growth of pines in the steppe zone of Buryatia. Geography and natural resources [Geografiia i prirodnye resursy], 1: 49-53 (in Russian)] 
Бабушкина Е.А., Белокопытова Л.В. (2014) Климатический сигнал в радиальном приросте хвойных в лесостепи юга Сибири и его зависимость от локальных условий местопроизрастания. Экология, 5: 323-332 [Babushkina E.A., Belokopytova L.V. (2014) A climate signal in the radial growth of coniferous species in the forest steppe in South Siberia and its dependence on local site conditions. Ecology [Ekologiia], 5: 323-332 (in Russian)]

Бабушкина Е.А., Кнорре А.А., Ваганов Е.А., Брюханова М.В. (2011) Трансформация климатического отклика в радиальном приросте деревьев в зависимости от топоэкологических условий их произрастания. География и природные ресурсы , 1: 159-166 [Babushkina E.A., Knorre A.A., Vaganov E.A., Bryukhanova M.V. (2011) Transformation of the climate response in the radial growth of trees depending on topoecological conditions of their growth. Geography and natural resources [Geografiia i prirodnye resursy], 1: 159-166 (in Russian)]

Вангниц П.Р. (1953) Ленточные боры. М., Гослесбумиздат, 153 с. [Vangnits P.R. (1953) Ribbon forests. Moscow, Goslesbumizdat, 153 p. (in Russian)]

Глызин А.В., Размахнина Т.Б., Корсунов В.М. (2005) Дендрохронологические исследования в контактной зоне «лес-степь» как источник информации об ее динамике. Сибирский экологический журнал, 1: 79-83 [Glyzin A.V., Razmakhnina T.B., Korsunov V.M. (2005) Dendrochronological study in a contact zone "forest-steppe" as a source of information about its dynamics. Siberian Journal of Ecology [Sibirskii ekologicheskii zhurnal], 1: 79-83 (in Russian)]

Грибанов Л.Н. (1954) Ленточные боры Алтайского края и Казахстана. М., Наука, 112 с. [Gribanov L.N. (1954) Ribbon forests of the Altai (Krai) Territory and Kazakhstan. Moscow, Nauka, 112 p. (in Russian)]

Дмитриева Е.В. (1982) Динамика прироста сосны в лесостепи Русской равнины. Ботанический журнал, 7 (403): 969-975 [Dmitrieva E.V. (1982) The dynamics of growth of pines in the foreststeppe of the Russian Plain. Botanical journal [Botanicheskii zhurnal], 7 (403): 969-975 (in Russian)]

Занин Г.В., Александрова В.Д., Кравцова В.И., Шаврыгин П.И. (1955) Природное районирование территории земель нового сельскохозяйственного освоения в Алтайском крае. Известия АН СССР. Сер. геогр., 2: 69-72 [Zanin G.V., Alexandrova V.D., Kravtsova V.I., Shavrygin P.I. (1955) Natural zoning of territories of the new agricultural development in the Altai (Krai) Territory. Proceedings of the Academy of Sciences of the USSR. Geography [Izvestiia AN SSSR. Geografiia], 2: 69-72 (in Russian)]

Занин Г.В. (1958) Геоморфология Алтайского края. Природное районирование Алтайского края. М., Изд-во АН CCCP, с. 62-98 [Zanin G.V. (1958) Geomorphology of the Altai (Krai) Territory. Natural zoning of the Altai (Krai) Territory. Moscow, Publishing House of the USSR Academy of Sciences, p. 62-98 (in Russian)]

Лютцау С.В. (1970) К проблеме происхождения боровых ложбин Приобского плато. Природа и природные ресурсы Алтая и Кузбасса. Ч. І. Бийск, с. 7-10 [Liuttsau SV. (1970) On the problem of the origin of the pine-forest dells in the Ob plateau. Nature and natural resources of the Altai and Kuzbass. Part 1. Biisk, p. 7-10 (in Russian)]

Магда В.Н. (2003) Радиальный прирост древесных растений как показатель увлажнения на юге Сибири: автореф. дис. ... канд. биол. наук: 03.00.16. Красноярск, 21 с. [Magda V.N. (2003) Radial growth of woody plants as a moisture index in South Siberia: Abstract of PhD thesis in Biology: 03.00.16. Krasnoyarsk, 21 p. (in Russian)] 
Магда В.Н., Ойдупаа О.Ч., Блок Й. (2004) Исследование географических особенностей климатического сигнала древесно-кольцевых хронологий методами кластерного анализа. Известия РГО, 136 (6): 46-53 [Magda V.N., Oidupaa O.Ch., Block I. (2004) Study of geographical features of the climate signal of tree-ring chronologies by the cluster analysis methods. Proceedings of the Russian Geographical Society [Izvestiia RGO], 136 (6): 46-53 (in Russian)]

Малышева Н.В. (2013) Климатические факторы, лимитирующие прирост сосны обыкновенной на южной границе ареала. География и природопользование Сибири: сборник научных статей под ред. Барышникова Г.Я. Вып.15. Барнаул, Изд-во Алтайского университета, с. 110-114 [Malysheva N.V. (2013) Climatic factors limiting the growth of Scots pine at the southern border of the area. Geography and natural resources managements of Siberia: a collection of scientific articles. Ed. by Baryshnikov G.Ia. V.15. Barnaul, Altai University, p. 110-114 (in Russian)]

Малышева Н.В., Быков Н.И. (2011) Дендроклиматический анализ ленточных боров Западной Сибири. Известия РАН. Сер. геогр., 6: 68-77 [Malysheva N.V., Bykov N.I. (2011) Dendroclimatic analysis of ribbon forests in Western Siberia. Proceedings of the Russian Academy of Science. Geography [Izvestiia RAN. Geografiia], 6: 68-77. (In Russian)]

Мандель И.Д. (1988) Кластерный анализ. М.: Финансы и статистика, 176 с. [Mandel' I.D. (1988) Cluster analysis. Moscow, Finance and Statistics, 176 p. (in Russian)]

Матвеев С.М. (2004) Дендроиндикаиия динамики состояния экосистем сосны обыкновенной (Pinus sylvestris L.) в лесостепи: дис. ... д-ра биол. наук: 03.00.16. Воронеж, 456 с. [Matveev S.M. (2004) Dendroindication of dynamics of ecosystems of Scots pine (Pinus sylvestris L.) in the forest-steppe: Doctoral thesis in Biology: 03.00.16. Voronezh, 456 p. (in Russian)]

Оленин C.М., Мазепа В.С. (1988) Прогноз климатически обусловленного радиального прироста сосны в ленточных борах Прииртышья. Экология, 5: 78-80 [Olenin S.M., Mazepa V.S. (1988) Prediction of climate-responsive radial growth of pines in ribbon forests in the Irtysh region. Ecology [Ekologiia], 5: 78-80 (in Russian)]

Правдин Л.Ф. (1964) Сосна обыкновенная. Изменчивость, внутривидовая систематика и селекиия. М., Наука, 191 с. [Pravdin L.F. (1964) Scots pine. Variability, intraspecific taxonomy and breeding. Moscow, Nauka, 191 p. (in Russian)]

Пугачев П.Г. (1975) Динамика годичного прироста Pinus sylvestris L. в Тургайской впадине в связи с климатическими факторами. Ботанический журнал, 60 (3): 401-412 [Pugachev P.G. (1975) The dynamics of annual growth of Pinus sylvestris L. in the Turgai basin due to climatic factors. Botanical Journal [Botanicheskii zhurnal], 60 (3): 401-412 (in Russian)]

Стрелковский А.Н. (2005) Экологические и морфологические особенности сосны обыкновенной на юге Западной Сибири: автореф. дис. ... канд. биол. наук. Новосибирск, 19 с. [Strelkovskii A.N. (2005) Ecological and morphological features of Scots pine in the south of Western Siberia: Abstract of PhD thesis in Biology. Novosibirsk, 19 p. (in Russian)]

Тишин Д.В. (2008) Дендроклиматические исследования ели финской (Picea x fennica (regel) Kom.) на южной границе ареала. Ученые записки Казанского государственного университета, 150 (4): 219-225 [Tishin D.V. (2008) Dendroclimatic study of Picea x fennica (regel) Kom. at the southern border of the area. Scientific notes of the Kazan State University [Uchenye zapiski KazGU], 150 (4): 219-225 (in Russian)] 
Шиманюк А.П. (1962) Сосновые леса Сибири и Дальнего Востока. М., Изд-во АН СССР, 187 c. [Shimaniuk A.P. (1962) Pine forests of Siberia and the Far East. Moscow, Publishing House of the USSR Academy of Sciences, 187 p. (in Russian)]

Шиятов С.Г., Ваганов Е.А., Кирдянов А.В., Круглов В.Б., Мазепа В.С., Наурзбаев М.М., Хантемиров Р.М. (2000) Методы дендрохронологии. Ч. І. Красноярск, Изд-во КрасГУ, 80 с. [Shiiatov, S.G., Vaganov, E.A., Kirdianov, A.V., Kruglov, V.B., Mazepa, V.S., Naurzbaev, M.M., Khantemirov, R.M. (2000) Methods of dendrochronology. Part 1. Krasnoyarsk State University, 80 p. (in Russian)]

Cook E.R, Kairiukstis L. (1990) Methods of dendrochronology: aplications in environmental sciences. Dordrecht, Boston, London, Kluwer Acad. Publ., 394 p.

Garcia-Gonzalez I. (2008) Comparison of different distance measures for cluster analysis of treering series. Tree-Ring Research, 64 (1): 27-37.

Grissino-Mayer H.D. (2001) Evaluating crossdating accuracy: a manual and tutorial for the computer program Cofecha. Tree-Ring Research, 57 (2): 205-211. URL: http://www.treeringsociety.org/ TRBTRR/ TRRvol57_2_205-221.pdf

Holmes R.L. (1983) Computer-assisted quality control in tree-ring dating and measurement. TreeRing Bulletin, 43: 69-78. URL: http://www.treeringsociety.org/TRBTRR/TRBvol43_69-78.pdf

Koese N., Akkemik Ue., Dalfes H.N., Oezeren M.S., Tolunay D. (2012) Tree-ring growth of Pinus nigra Arn. subsp. pallasiana under different climate conditions throughout Western Anatolia. Dendrochronology, 30: 295-301.

Rinn F. (1996) TSAP-Reference Manual. Heidelberg, 263 p. 